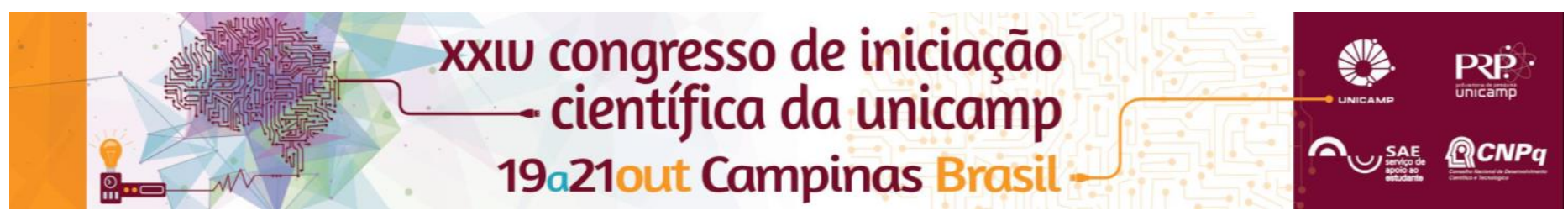

\title{
Rompendo o Silêncio: Violência nas Revistas Acadêmicas de Gênero e Feministas
}

\author{
Janaina Ap. Alves de Oliveira*, Bianca Dantas G. da Silva, Jaqueline Squizzato, Lucila Scavone.
}

\section{Resumo}

Este trabalho pretende analisar o tema violência em três Revistas Acadêmicas de Gênero e Feministas, presentes em diferentes regiões do Brasil.

\author{
Palavras-chave: \\ Violência de Gênero, Revistas Acadêmicas de Gênero e Feministas, Feminismo.
}

\section{Introdução}

Entendemos que as formas de violência são resultantes das relações de poder, dominação e desigualdade entre os gêneros e estão inter-relacionadas às questões como raça/etnia e classe.

Neste trabalho buscamos analisar a discussão sobre Violência em três Revistas Acadêmicas de Gênero e Feministas, com o propósito de verificar como a temática é abordada no âmbito científico, social e político. As revistas analisadas são: Revista Ártemis (UFPB), Revista Gênero (UFF) e a Revista Latino-americana de Geografia e Gênero (UEPG). O estudo está vinculado ao projeto de pesquisa Revistas Acadêmicas de Gênero e Feministas, sob orientação da Prof. ${ }^{a}$ Dr. ${ }^{a}$ Lucila Scavone (CNPq 2013 -).

O objetivo geral consiste em verificar se a produção dessas revistas aborda os debates acadêmicos acerca da temática e se eles dialogam com as problemáticas apresentada pelos Movimentos de Mulheres.

Os objetivos específicos se atêm a maneira como o tema Violência é desenvolvido em cada revista.

Para compreender tais aspectos utilizamos a categoria de gênero como análise, por remeter às relações de poder presentes na construção do masculino e do feminino.

\section{Resultados e Discussão}

A metodologia desta pesquisa seguiu a do projeto maior, no qual todos os artigos foram arquivados - por seus títulos, palavras-chave, autoria - em um Banco de Dados da pesquisa Revistas Acadêmicas de Gênero e Feministas (Scavone, 2013 -CNPq). O universo de nossa pesquisa se refere ao período de 2000-2012 e consiste em 32 artigos: a Revista Ártemis compõe 15 artigos, a Revista Gênero 10 artigos e a Revista Latino Americana de Geografia e Gênero 7 artigos. Primeiramente, buscamos títulos e palavras-chave como Violência, Violência de Gênero e Femicídio. Posteriormente realizamos a leitura dos respectivos resumos e por fim a leitura dos artigos cuja a temática apresentava maior incidência.

Dos 32 artigos analisados, $18,75 \%$ discutem violência sexual, outros $18,75 \%$ violência de gênero e os $62,5 \%$ restantes apresentam temas como violência doméstica, contra travesti, homofobia e femicídio (Gráfico 1).

A discussão sobre violência sexual é apresentada em sua maioria como uma prática exercida contra mulheres e menores de 18 anos. Essa transgressão aos direitos humanos estaria relacionada ao ato de dominação do homem sobre a mulher, como uma representação e autoafirmação de sua masculinidade (CANÇADO, 2012), manifestada tanto na sua forma física, quanto psíquica e simbólica.

Embora a temática violência de gênero seja expressiva, o assunto perpassa todos os artigos. Defende-se a importância do uso da categoria de gênero como análise (SCOTT, 1990) por ser um conceito que abrange perspectivas que possibilitam a compreensão do sistema patriarcal.

Gráfico 1. Violência nas Revistas Acadêmicas de Gênero e Feministas

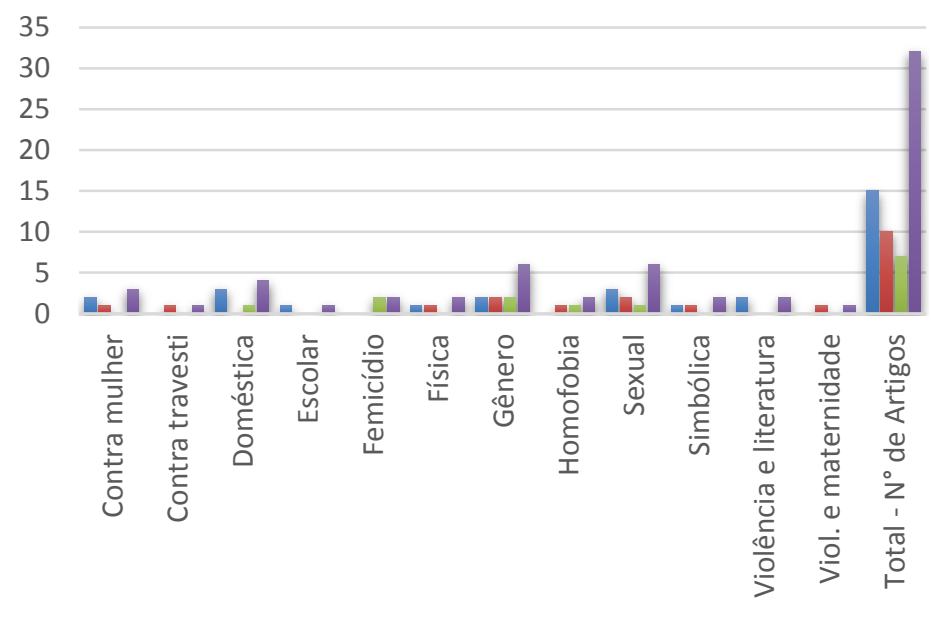

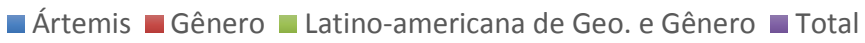

\section{Conclusões}

As discussões apresentadas pelos artigos no período analisado fundamentaram debates que transgrediram as esferas privadas, contribuíram para formulação de políticas e ganharam espaço na opinião pública.

\section{Agradecimentos}

Agradecemos ao Movimento de Mulheres, à Lucila Scavone, ao Núcleo de Estudos de Gênero de Araraquara e ao CNPq.

CANÇADO, A. T. M. Violência Sexual Contra Crianças e Adolescentes: um estudo do incesto na perspectiva de gênero. Revista Latino-americana de Geografia e Gênero, Ponta Grossa, v.3, n.1, jan./jul. 2012. p. 154-163.

SAFFIOTI, H. Contribuições feministas para o estudo da violência de gênero. Cadernos Pagu, n.16, 2001. p.115-136.

SCAVONE, L. Perfil da REF dos anos 1999-2012. Revista Estudos Feministas (UFSC. Impresso), v. 21, p. 587-596, 2013.

SCOTT, J. Gênero: uma categoria útil de análise histórica. Educação e Realidade. Porto Alegre, v.16, n. 2, 1990. p.5-22 